\title{
Speed distribution in the exhaust diffuser of the air fan
}

\author{
Ion Gherghe ${ }^{1 *}$, Doru Cioclea ${ }^{1}$, Florin Rădoi ${ }^{1}$, Emeric Chiuzan ${ }^{1}$, and Răzvan Drăgoescu ${ }^{1}$ \\ ${ }^{1}$ National Institute for Research and Development in Mine Safety and Protection to Explosion - \\ INSEMEX, 32-34 G-ral Vasile Milea Street, Petroșani, Hunedoara, Romania
}

\begin{abstract}
A perfect connection between the column and the fan is that which ensures an air inlet in the fan, evenly distributed, over the entire surface of the suction mouth and an air outlet from the fan outlet made in a way that allows the full use of developed pressure. For both suction and exhaust, fans must be equipped with a device/diffuser. When the fan discharges freely into the atmosphere without any connection, a loss equivalent to $50 \%$ of the average dynamic pressure at the discharge port occurs. If the fan discharges into a speaker, the loss depends on its angle. At a peak angle of $30^{\circ}$ corresponds to a loss of $\approx 25 \%$ of the average dynamic pressure in the discharge mouth, and to reduce air vortices the speakers must be built at an angle of inclination to vertical or horizontal between $12-15^{\circ}$, in order to reduce the aerodynamic resistances. The paper will present the speed field distribution of an axial fan located on a circular duct, provided on the air discharge side with a diffuser with a length of $1.5 \mathrm{~m}$, at an angle of inclination to the vertical or horizontal of $12^{\circ}$.
\end{abstract}

\section{Introduction}

Industrial ventilation and air conditioning installations aim to ensure air purity and microclimate conditions corresponding to human activity and the nature of the technological process. Achieving these requirements contributes to maintaining work capacity, eliminating occupational diseases, raising labor productivity, product quality, etc.

The fresh air supply system (discharge) comprises a fresh air intake from the outside, a ventilation unit as appropriate, and a network of discharge pipes in the room.

The defective air intake system (exhaust) consists of a network of ducts with suction ports, a fan located on the main suction pipe and a defective air exhaust device.

When both fresh air is sucked in and exhaust air is flushed, the fans must be fitted with a diffuser. To reduce air vortices, the diffusors are built at an angle of inclination to vertical or horizontal between $12-15^{\circ}$, in order to reduce the aerodynamic resistance. [1].

\section{The influence of the connection mode on the performance of a} fan

\footnotetext{
* Corresponding author: ion.gherghe@insemex.ro
} 
The fan is the active aerodynamic element of a ventilation system. A fan is a dynamic rotating device and is the part that moves all mechanical ventilation systems. The rotational energy applied to the fan shaft is transformed into a pressure difference by causing air, gas or dust particles to float through the ventilation duct or to be evacuated into a free space.

The connection between the column and the fan must be perfect to ensure the entry of air into the fan, evenly distributed over the entire surface of the suction mouth, the air outlet from the fan outlet must be made in a way that allows the full use of the developed pressure. Only under these conditions can the fan provide the parameters that correspond to the operating point. At both suction and exhaust, the fans must be equipped with diffuser. [1, 3 , $5]$

\subsection{Effect of connection to fan suction mouth}

In order to obtain from a fan the maximum capacity at its disposal, under given operating conditions, it is necessary that the air enters the suction mouth at the same velocity at all points of the suction area and by a linear movement, without movement of rotation. A disturbance that causes an unevenness in the air distribution loads more parts of the rotor and discharges others, which leads to an uneven distribution of mechanical work in the rotor and a lower overall amount of mechanical work performed. (Al. Cristea, 1968),

If air enters the rotor at an angle of $30^{\circ}$, the air flow supplied by the fan decreases by about $15 \%$, and at an angle of $45^{\circ}$ corresponds to a decrease in flow of about $25 \%$.

In order to assess the likely effects of the different ways of connecting the suction ports of the fans, tables have been prepared showing how much the flow decreases in the presence of an unfavorable part and how much the static pressure must be increased when choosing fans to compensate.

To reduce air loss, front nozzles are placed on the suction side called conffusers.

There are several constructive types of conffusers, in figure no. 1 being presented the main geometric characteristics of this conffuser with variation of the section in a single plane and double curvature, with curvilinear generators $[1,2,8]$

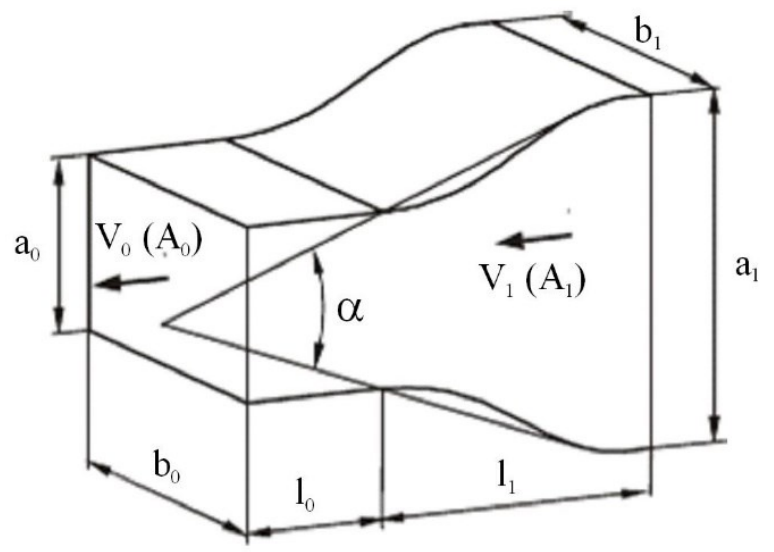

Fig. 1 Confusing with single-plane section variation and double curvature with curvilinear generators

\subsection{The effect of the connection to the fan outlet}

In terms of the fan outlet, the velocity distribution is not uniform. The centrifugal force that arises in the rotating air mass inside the fan housing blows the air to the outside of the 
discharge mouth. If a straight pipe of sufficient length is connected to the discharge outlet in the fan, the air flow is even.

When the fan discharges freely into the atmosphere without any connection, a loss equivalent to $50 \%$ of the average dynamic pressure at the discharge port occurs. To compensate for this effect, the loss thus calculated must be added to the mains resistance, and the fan must be chosen from the catalogue for the resulting increased pressure.

If the fan discharges into a diffusor, the loss depends on its angle. At a peak angle of the $30^{\circ}$ diffuser corresponds to a loss of $\approx 25 \%$ of the average dynamic pressure in the discharge mouth [1].

A diffusor consists of an increasing section channel, and the velocity of the air stream decreases progressively from the inlet to the outlet. Here takes place the transformation of kinetic energy into potential (pressure).

For circular sections the maximum recommended value of the flaring angle of the walls is approximately $\alpha \approx 6^{\circ}$. This value can reach $\alpha \mathrm{D} \approx 12^{\circ}$, in the case of rectangular sections, where the increase of the section is achieved, frequently, by flaring in a single plane as in the case presented in figure no. $2[1,6,8]$.

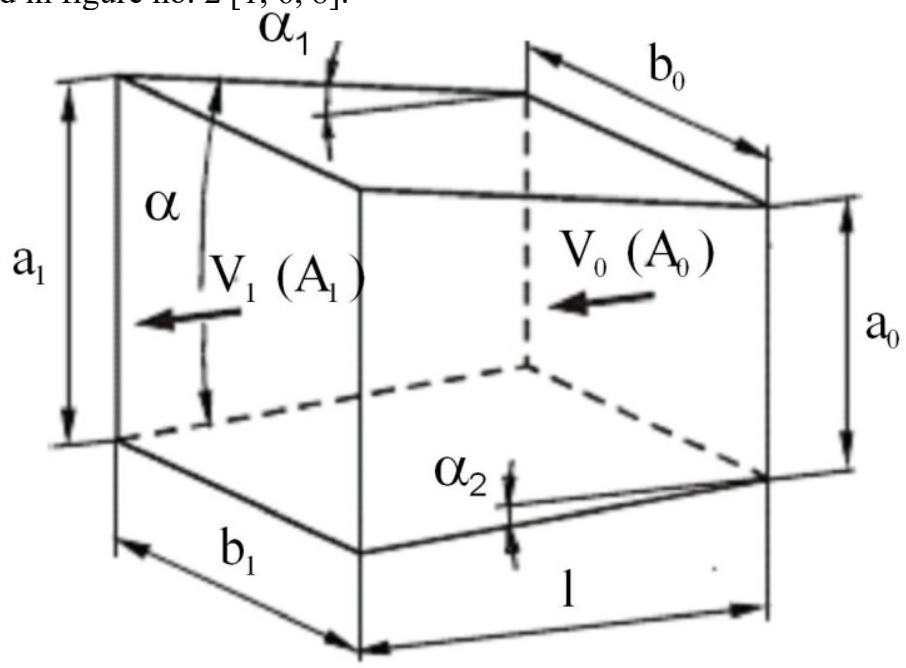

Fig. 2 Rectangular speaker

\section{Setting the velocity field at the diffusor level}

Both electronic and mechanical devices can be used to measure the airflow in pipes.

In columns and installations for local ventilation, the method consists in measuring the velocity of the air flow in the center of the ventilation tube. It is noted that the air flow velocity inside the tube columns can be determined using the Pitot-Prandtl tube and an electronic recorder / manometer, where the dynamic air flow depression and air velocity are measured $[3,4,5,7,9,10]$

\subsection{Using the Pitot-Prandtl Tube}

The Pitot - Prandtl tube is inserted into the column of tubes through two holes drilled on two perpendicular diameters positioned with the end bent in the opposite direction to the air flow, in a position perpendicular to the axis of the tube. The connection between the two nozzles of the Pitot tube and the apparatus for determining the pressure drop is made by a flexible 
hose. The principal diagram of the Pitot - Prandtl tube is presented in figure no. 3. $[1,3,4,6$, $9,10]$

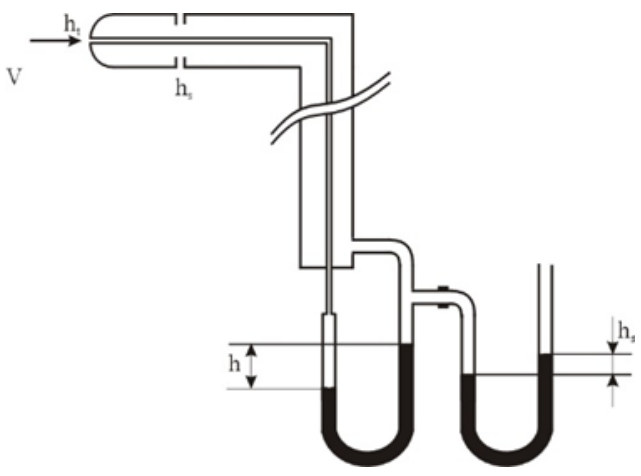

Fig. 3 Pitot tube - Prandtl - Scheme of principle

Depending on how the depressor or micromanometer is coupled to the Pitot tube, the following can be measured:

$>$ static depression (pressure) (hs);

$>$ total depression (pressure) (ht);

$>$ dynamic depression (pressure) (hd):

The hole in the column of tubes for inserting the Pitot-Prandtl tube will be drilled at the following distances from the fan:

- $5 \mathrm{Dm}$ - in case of suction ventilation;

- $10 \mathrm{Dm}$ - in the case of discharge ventilation.

$\mathrm{D}$ - the diameter of the tube column

Since the airflow velocity distribution is uneven in the section of the tube column, it is divided into " $n$ " concentric circular columns $\left(\mathrm{S}_{1}, \mathrm{~S}_{2}, \ldots, \mathrm{Sn}\right)$ so that it can be admitted that in each of them there is a uniform velocity, according to figure no. 4 . [1, 3, 4, 5, 6, 7, 9]

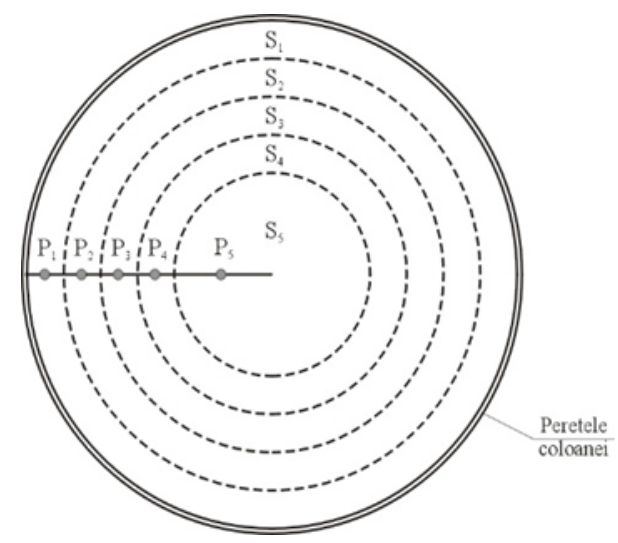

Fig. 4 Position of measuring points in a section of ventilation columns $(n=5)$

For each of the points $\mathrm{P} 1 \div \mathrm{P} 5$, the values of the dynamic depression (pressure) corresponding to the two perpendicular diameters are measured, calculating the value of the average dynamic depression corresponding to each diameter.

\subsection{Results obtained}


For experimenting with the industrial ventilation system in order to establish the velocity fields at the level of the diffuser, measurements were performed on a ventilation installation consisting of an axial fan, a reduction and a diffuser with lengths of $1.5 \mathrm{~m}$.

The measurements were performed at an air temperature of $16.5^{\circ} \mathrm{C}$, air humidity of $42 \%$ $\mathrm{RH}$ and atmospheric pressure of $947 \mathrm{hPa}$.

The stand for performing velocity field measurements at the level of the diffusor with a length of $1.5 \mathrm{~m}$ on which sets of two holes were drilled, on five different sections, on five perpendicular diameters D1 - D2, D3 - D4, D5 - D6, D7 -D4 respectively D9 and D10, is presented in figure no. 5 .

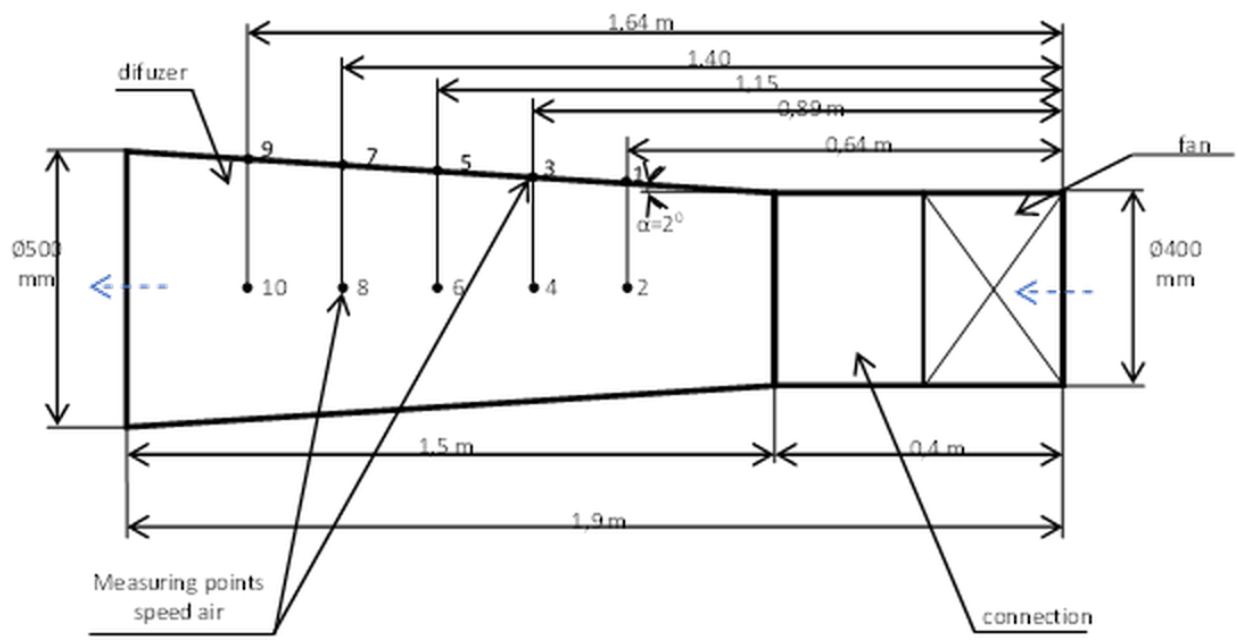

Fig. 5 Stand for setting the velocity field at the diffusor

For each of the ten measuring points corresponding to the five diameters $(0.418 \mathrm{~m}, 0.436$ $\mathrm{m}, 0.452 \mathrm{~m}, 0.47 \mathrm{~m}$ and $0.49 \mathrm{~m}$ ), sets of ten measurements of the air circulation velocity were performed, namely, minimum, maximum and average velocity, at each point on each circular surface performing three measurements. The field of air flow velocities inside the diffuser was determined using the Pitot-Prandtl tube and a KIMO AMI 310 PRF electronic device.

The results of the obtained measurements are presented in table no. 1, in accordance with the measurement points presented in figure no. 5 .

Table 1. Results of measurements made in the $1.5 \mathrm{~m}$ long diffusor

\begin{tabular}{|c|c|c|c|c|c|c|c|}
\hline \multirow{2}{*}{ No. } & \multirow{2}{*}{$\begin{array}{c}\text { Pitot tube } \\
\text { insertion } \\
\text { distance from } \\
\text { the lower edge } \\
\text { of the tube } \\
{[\mathrm{mm}]}\end{array}$} & \multicolumn{6}{|c|}{ Air velocity } \\
\hline & & $\begin{array}{c}V_{\text {med }} \\
{[\mathrm{m} / \mathrm{s}]}\end{array}$ & $\begin{array}{c}\mathrm{V}_{\min } \\
{[\mathrm{m} / \mathrm{s}]}\end{array}$ & $\begin{array}{c}\mathrm{V}_{\max } \\
{[\mathrm{m} / \mathrm{s}]}\end{array}$ & $\begin{array}{c}V_{\text {med }} \\
{[\mathrm{m} / \mathrm{s}]}\end{array}$ & $\begin{array}{c}V_{\min } \\
{[\mathrm{m} / \mathrm{s}]}\end{array}$ & $\begin{array}{c}\mathrm{V}_{\max } \\
{[\mathrm{m} / \mathrm{s}]}\end{array}$ \\
\hline \multicolumn{8}{|c|}{$\varphi=418 \mathrm{~mm}$} \\
\hline & & \multicolumn{3}{|c|}{ Diameter $\mathrm{D}_{1}$} & \multicolumn{3}{|c|}{ DiameterD $_{2}$} \\
\hline 1. & 10,87 & 19,79 & 17,5 & 22,6 & 22,75 & 21,2 & 24,1 \\
\hline 2. & 34,27 & 27,66 & 26,0 & 28,7 & 24,16 & 23,2 & 24,8 \\
\hline 3. & 61,03 & 26,06 & 24,6 & 27,3 & 23,82 & 23,2 & 24,5 \\
\hline 4. & 94,47 & 17,71 & 16,4 & 20,4 & 21,09 & 19,8 & 22,8 \\
\hline
\end{tabular}




\begin{tabular}{|c|c|c|c|c|c|c|c|}
\hline 5. & 142,95 & 6,55 & 4,0 & 9,0 & 14,17 & 13,3 & 15,7 \\
\hline 6. & 275,04 & 10,75 & 9,0 & 12,9 & 8,19 & 5,6 & 10,5 \\
\hline 7. & 323,53 & 17,49 & 15,8 & 19,7 & 15,98 & 13,8 & 18,0 \\
\hline 8. & 356,97 & 22,52 & 19,8 & 24,9 & 21,93 & 20,1 & 24,3 \\
\hline 9. & 483,72 & 24,12 & 22,9 & 25,5 & 28,49 & 28,1 & 29,2 \\
\hline 10. & 407,13 & 19,5 & 18,0 & 21,0 & 20,65 & 19,4 & 22,5 \\
\hline \multicolumn{2}{|c|}{ Average velocity of points } & 19,215 & - & - & 20,123 & - & - \\
\hline \multicolumn{2}{|c|}{$\begin{array}{l}\text { Velocity in the center of } \\
\text { the column }\end{array}$} & 5,0 & 3,8 & 8,0 & 6,12 & 3,3 & 8,0 \\
\hline \multicolumn{2}{|c|}{ Total average velocity } & 17,922 & - & - & 18,85 & - & - \\
\hline \multicolumn{8}{|c|}{$\varphi=436 \mathrm{~mm}$} \\
\hline & & \multicolumn{3}{|c|}{ Diameter $\mathrm{D}_{1}$} & \multicolumn{3}{|c|}{ Diameter $\mathrm{D}_{2}$} \\
\hline 1. & 11,33 & 21,3 & 20,0 & 22,5 & 25,34 & 24,3 & 26,1 \\
\hline 2. & 35,75 & 22,51 & 21,9 & 23,5 & 24,66 & 23,0 & 25,2 \\
\hline 3. & 63,66 & 21,22 & 20,3 & 21,9 & 22,10 & 19,9 & 23,2 \\
\hline 4. & 98,53 & 19,52 & 17,8 & 20,8 & 15,81 & 13,8 & 18,8 \\
\hline 5. & 149,11 & 14,64 & 11,6 & 16,7 & 10,23 & 8,7 & 12,0 \\
\hline 6. & 286,88 & 10,47 & 8,1 & 12,3 & 14,99 & 12,7 & 16,7 \\
\hline 7. & 337,46 & 16,05 & 14,3 & 18,1 & 19,95 & 18,5 & 21,3 \\
\hline 8. & 372,34 & 21,01 & 19,1 & 22,6 & 19,33 & 17,8 & 20,4 \\
\hline 9. & 400,25 & 22,02 & 20,6 & 24,1 & 18,05 & 17,0 & 19,4 \\
\hline 10. & 424,66 & 18,73 & 16,3 & 20,3 & 16,35 & 15,1 & 18,0 \\
\hline \multicolumn{2}{|c|}{ Average velocity of points } & 18,747 & - & - & 18,681 & - & - \\
\hline \multicolumn{2}{|c|}{$\begin{array}{l}\text { Velocity in the center of } \\
\text { the column }\end{array}$} & 9,18 & 7,2 & 11,9 & 9,44 & 6,7 & 11,0 \\
\hline \multicolumn{2}{|c|}{ Total average velocity } & 17,877 & - & - & 17,840 & - & - \\
\hline \multicolumn{8}{|c|}{$\varphi=452 \mathrm{~mm}$} \\
\hline & & \multicolumn{3}{|c|}{ Diameter $\mathrm{D}_{1}$} & \multicolumn{3}{|c|}{ Diameter $\mathrm{D}_{2}$} \\
\hline 1. & 11,75 & 19,25 & 16,3 & 20,8 & 19,75 & 17,7 & 21,2 \\
\hline 2. & 37,06 & 22,36 & 21,6 & 22,9 & 20,97 & 20,1 & 21,8 \\
\hline 3. & 65,99 & 21,96 & 20,6 & 23,7 & 17,95 & 16,6 & 19,8 \\
\hline 4. & 102,15 & 19,37 & 17,9 & 21,3 & 14,53 & 13,1 & 16,5 \\
\hline 5. & 154,58 & 13,82 & 11,2 & 15,2 & 11,96 & 9,5 & 14,9 \\
\hline 6. & 297,41 & 11,85 & 6,2 & 13,8 & 12,82 & 11,4 & 14,0 \\
\hline 7. & 349,85 & 14,58 & 12,3 & 16,2 & 16,92 & 5,4 & 19,1 \\
\hline 8. & 386,00 & 16,73 & 15,3 & 18,2 & 17,37 & 16,1 & 18,5 \\
\hline 9. & 414,94 & 17,16 & 14,8 & 19,0 & 16,4 & 15,6 & 17,5 \\
\hline 10. & 440,24 & 13,56 & 11,6 & 15,1 & 11,96 & 11,2 & 12,9 \\
\hline \multicolumn{2}{|c|}{ Average velocity of points } & 17,064 & - & - & 16,063 & - & - \\
\hline \multicolumn{2}{|c|}{$\begin{array}{l}\text { Velocity in the center of } \\
\text { the column }\end{array}$} & 11,96 & 9,3 & 13,4 & 15,23 & 13,0 & 17,7 \\
\hline \multicolumn{2}{|c|}{ Total average velocity } & 16,60 & - & - & 15,987 & - & - \\
\hline \multicolumn{8}{|c|}{$\varphi=470 \mathrm{~mm}$} \\
\hline & & \multicolumn{3}{|c|}{ Diameter $\mathrm{D}_{1}$} & \multicolumn{3}{|c|}{ Diameter $\mathrm{D}_{2}$} \\
\hline 1. & 12,22 & 20,54 & 20,1 & 21,2 & 18,53 & 17,3 & 19,5 \\
\hline 2. & 38,54 & 21,28 & 20,4 & 22,0 & 16,48 & 14,3 & 18,6 \\
\hline 3. & 68,62 & 18,39 & 17,1 & 19,4 & 14,02 & 11,4 & 14,6 \\
\hline 4. & 106,22 & 14,94 & 13,6 & 17,1 & 14,62 & 12,0 & 15,8 \\
\hline 5. & 160,74 & 13,75 & 12,0 & 14,9 & 11,7 & 10,30 & 13,4 \\
\hline
\end{tabular}




\begin{tabular}{|c|c|c|c|c|c|c|c|}
\hline 6. & 309,26 & 12,14 & 10,6 & 14,7 & 17,28 & 15,5 & 19,2 \\
\hline 7. & 363,78 & 13,5 & 12,2 & 14,8 & 18,6 & 18,0 & 20,1 \\
\hline 8. & 401,38 & 14,54 & 13,7 & 15,8 & 19,41 & 18,9 & 20,0 \\
\hline 9. & 431,46 & 12,82 & 13,6 & 16,2 & 19,10 & 18,6 & 20,2 \\
\hline 10. & 457,78 & 11,49 & 11,6 & 14,4 & 14,5 & 13,6 & 16,2 \\
\hline \multicolumn{2}{|c|}{ Average velocity of points } & 15,339 & - & - & 16,404 & - & - \\
\hline \multicolumn{2}{|c|}{$\begin{array}{l}\text { Velocity in the center of } \\
\text { the column }\end{array}$} & 12,38 & 10,9 & 13,4 & 13,06 & 11,3 & 14,4 \\
\hline \multicolumn{2}{|c|}{ Total average velocity } & 15,07 & - & - & 16,1 & - & - \\
\hline \multicolumn{8}{|c|}{$\varphi=490 \mathrm{~mm}$} \\
\hline & & \multicolumn{3}{|c|}{ Diameter $\mathrm{D}_{1}$} & \multicolumn{3}{|c|}{ Diameter $\mathrm{D}_{2}$} \\
\hline 1. & 12,74 & 17,69 & 16,7 & 18,6 & 16,36 & 14,9 & 17,8 \\
\hline 2. & 40,18 & 19,09 & 18,1 & 20,0 & 15,34 & 13,2 & 17,4 \\
\hline 3. & 71,54 & 17,46 & 16,4 & 19,9 & 13,71 & 10,9 & 15,3 \\
\hline 4. & 110,74 & 14,7 & 13,4 & 16,0 & 12,99 & 11,4 & 14,5 \\
\hline 5. & 176,58 & 13,24 & 12,3 & 14,0 & 11,46 & 9,2 & 12,7 \\
\hline 6. & 322,42 & 12,66 & 11,1 & 14,8 & 15,63 & 14,1 & 16,9 \\
\hline 7. & 379,26 & 13,56 & 12,5 & 14,9 & 17,44 & 16,4 & 18,2 \\
\hline 8. & 418,46 & 13,89 & 13,1 & 14,5 & 17,97 & 16,7 & 18,9 \\
\hline 9. & 449,82 & 12,06 & 10,9 & 13,1 & 17,55 & 16,9 & 18,6 \\
\hline 10. & 477,26 & 10,59 & 9,3 & 12,3 & 15,06 & 13,9 & 16,8 \\
\hline \multicolumn{2}{|c|}{ Average velocity of points } & 14,494 & - & - & 15,351 & - & - \\
\hline \multicolumn{2}{|c|}{$\begin{array}{l}\text { Velocity in the center of } \\
\text { the column }\end{array}$} & 12,44 & 11,2 & 13,5 & 12,67 & 11,4 & 14,3 \\
\hline \multicolumn{2}{|c|}{ Total average velocity } & 14,307 & - & - & 15,107 & - & - \\
\hline
\end{tabular}

For the ten diameters on which air velocity measurements were performed, the diagrams of the velocity fields presented in figures no. 6-10.

Field of velocities for a diffusor of $1.5 \mathrm{~m}$, diameters D1 and D2 $(0,418 \mathrm{~m})$, vertical - horizontal

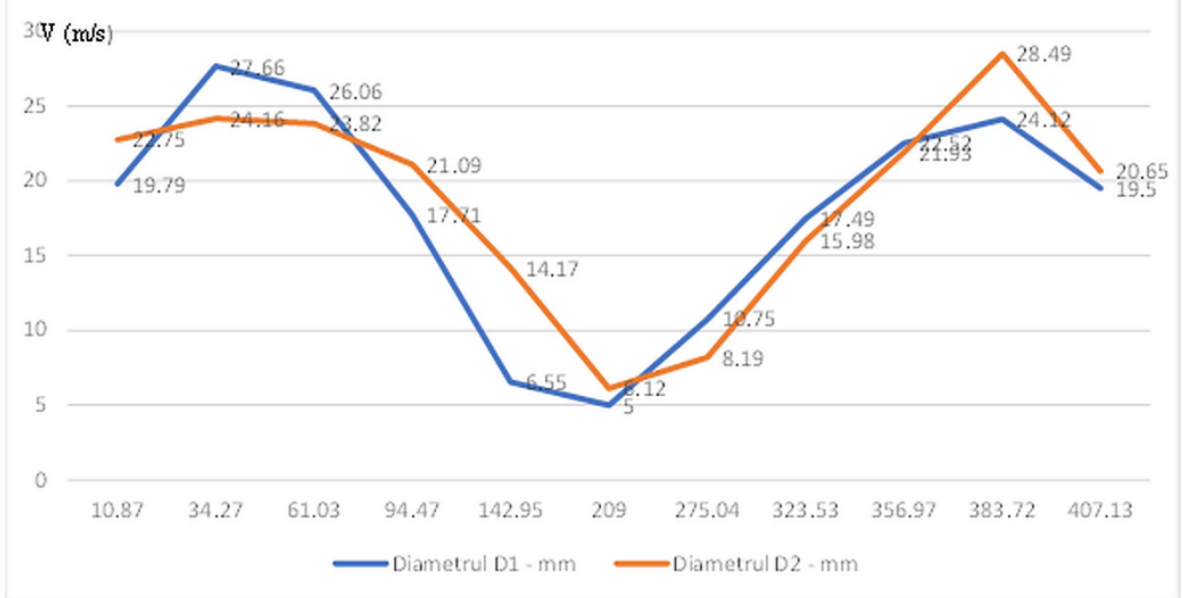

Fig. 6 Field of velocities on diameters D1-D2 - diffusor with a length of $1.5 \mathrm{~m}$ 
$\mathrm{V}$
$(\mathrm{m} / \mathrm{s})$$\quad$ Field of velocities for a diffuser of $1.5 \mathrm{~m}$, diameters D3 și D4 (0,436 m), vertical horizontal

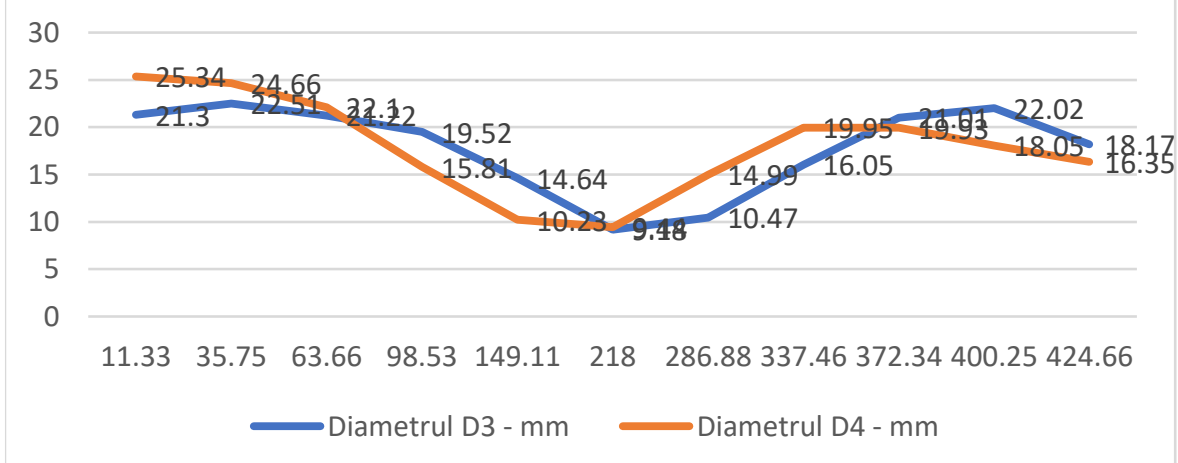

Fig. 7 Field of velocities on diameters D3-D4 - diffusor with a length of $1.5 \mathrm{~m}$

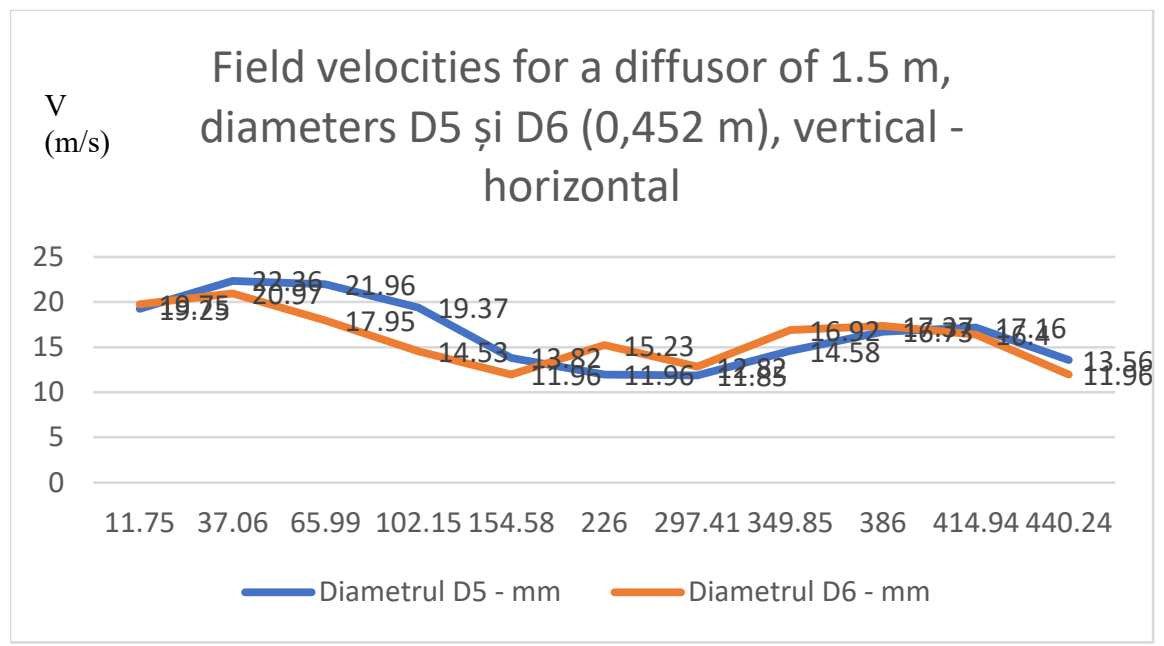

Fig. 8 Field of velocities on diameters D5-D6 - diffusor with a length of $1.5 \mathrm{~m}$ 


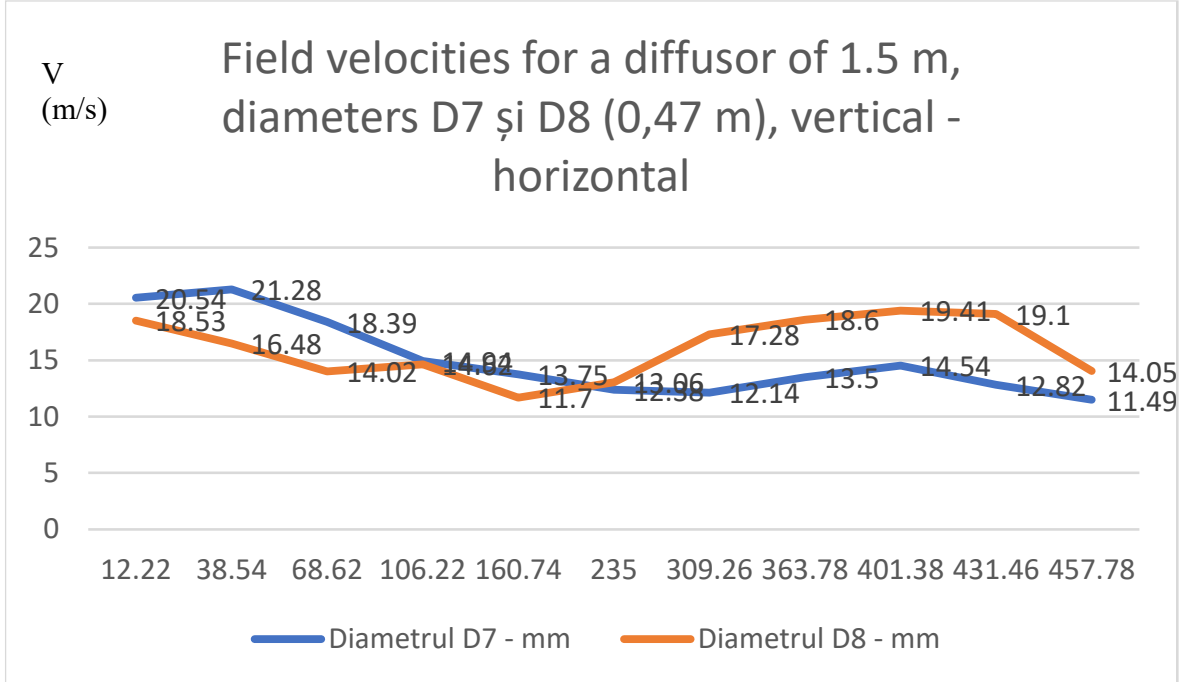

Fig. 9 Field of velocities on diameters D7-D8 - diffusor with a length of $1.5 \mathrm{~m}$

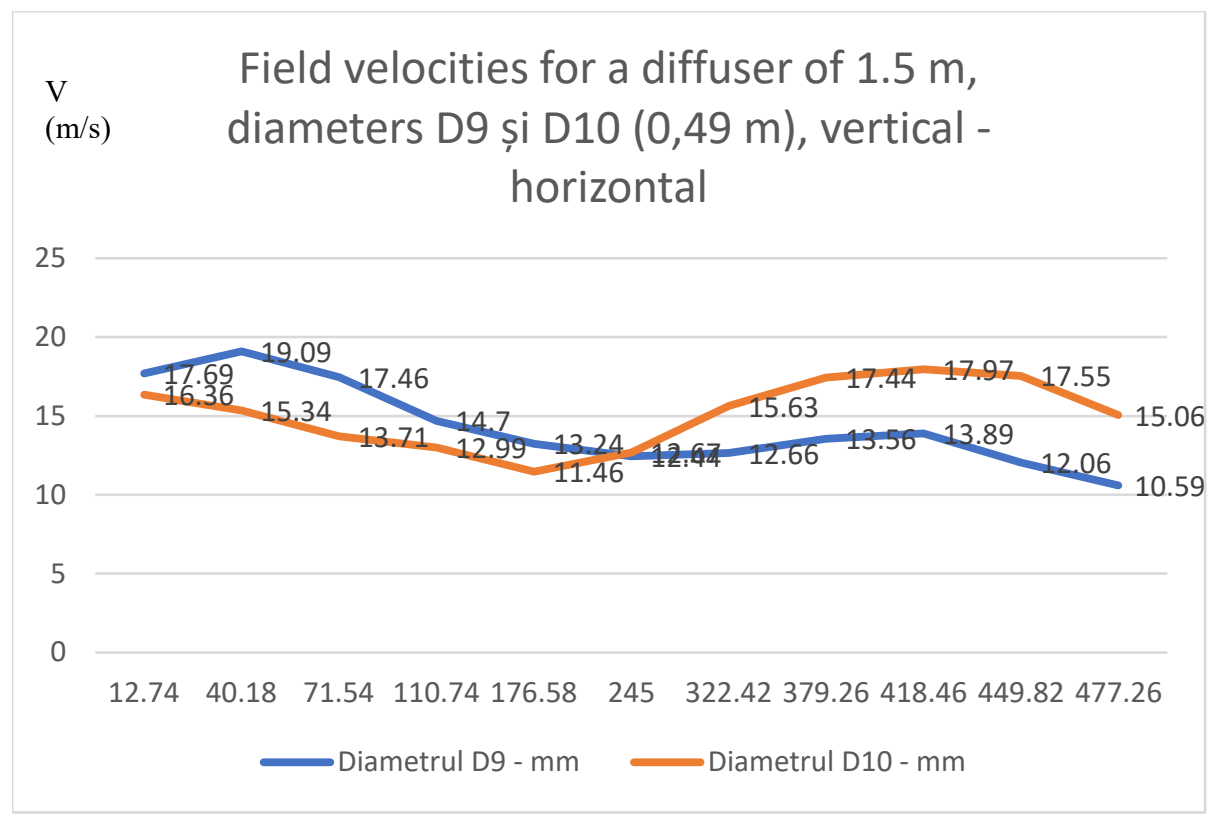

Fig. 10 - Field of velocities on diameters D9-D10 - diffusor with a length of $1.5 \mathrm{~m}$

From the diagrams presented in figures no. 6-10 the following findings can be deduced:

- the air speed has a lower value next to the diffuser tubing, which increases and then decreases towards its interior;

- in the center of the diffuser the air speeds have quite low values being almost $80 \%$ lower than the maximum measured velocity;

- these relatively low values of air velocity in the center of the diffuser are due to the configuration of the axial fan with the help of which the measurements were made, it has 
a diameter of $15 \mathrm{~cm}$ corresponding to the propeller which is attached to the rotor of the drive motor, and which closes part of the section of the diffuser.

\section{Conclusions}

A perfect connection between the column and the fan is one which ensures an air inlet in the fan, evenly distributed over the entire surface of the suction mouth and an air outlet from the fan outlet made in a way that allows the full use of the developed pressure;

The field of air flow velocities inside the diffuser was determined using the Pitot-Prandtl tube and a KIMO AMI 310 PRF electronic device.

The measurement of the air velocity $(\mathrm{m} / \mathrm{s})$ was performed on surfaces of equal pressures with equal velocity fields, perpendicular to the direction of air flow, on two perpendicular diameters D1 and D2.

The velocity of the air from the diffuser wall towards its center has an increasing value after which it decreases suddenly towards the interior of the diffuser (D1-D2) representing $11.74-28.5 \%$ of the maximum measured velocity.

In the center of the diffusor, the air velocity showed values by almost $88 \%$, lower than the maximum measured velocity;

As the measuring distance increases with respect to the axial fan and the diffuser wall, the air velocity increases proportionally to about $60 \%$ of the maximum measured velocity (diameters D7-D10).

These relatively low velocity values in the center of the diffusor are due to the configuration of the axial fan with which these measurements were made.

This uniformity of the velocity field inside the diffusor is due to the angle at which the diffusor is executed and its length.

This paper was developed within the Nucleu-Programme, carried out with the support of MCID, project no.PN 19210204

\section{References}

1. Al. Cristea, Ventilarea și condiționarea aerului, Volumul I, (Editura Tehnică, București, 1968)

2. O. Bancea, Sisteme de ventilare industrială, (Editura Politehnică, Timișoara, 2009)

3. I. Matei, R. Moraru, M. Samoilă, G. Băbuț, Ingineria mediului și ventilația în subteran, (Editura

Tehnică București, 2000)

4. W. A. Burgess, M. J. Ellenbecker, R. D. Treitman, Ventilation for control of the work environment - second edition, (Copyright $\mathbb{C} 2004$ John Wiley \& Sons, Inc.)

http://healthf.kaums.ac.ir/UploadedFiles/jozveh/motalebi/

VENTILATIONFORCONTROLOFTHEWORKENVIRONMENT.pdf [Accessed 22 September 2016]

5. D. Cioclea, C. Lupu, I. Gherghe, Ghid pentru dimensionarea instalațiilor de ventilație industrială, (Editura INSEMEX, 2013)

6. H. Goodfellow, E. Tahti, Industrial Ventilation, Desing Guidebook, (Academic Press, 2001)

7. I. Gherghe, D. Cioclea, Metodologie de măsurare a vitezei de curgere a aerului în conducte, (INCD INSEMEX Petroșani, 2018)

8. N. Niculescu, Gh. Duță, P. Stoenescu, I. Colda, Instalații de ventilare și climatizare, (E.D.P., București, 1982)

9. W.L. Le Roux, Mine ventilation notes for beginners, (Published the mine ventilation society of South Africa - Printed by CTP Printers (Transvaal) Limited - 2nd Edition 1972)

10. J. H. J. Burrows, R. Hemp, F. H. Lancaster, J. H. Quilliam, The ventilation of South African Gold Mines, (Printed by Cape\& Transvaal Printers Ltd, Cape Town, 1974) 